\title{
ONIMICZNY OBRAZ ŚWIATA W TŁUMACZENIU POPRZEZ JEZZYK TRZECI NA PRZYKŁADZIE ANTROPONIMÓW W ZBIORZE „ZBIERACZ POROSTÓW” AUTORSTWA ZHANG WEIA ${ }^{1}$
}

Słow a tematyczne: antroponomastyka, lingwistyka kulturowa, antroponimy chińskie, językowy obraz świata, onimiczny obraz świata

\section{WSTĘP}

Artykuł łączy teorię językowego obrazu świata, onomastyki i przekładoznawstwa. Egzemplifikacją problematyki są antroponimy występujące w opowiadaniach „Zbieracz porostów” autorstwa Zhang Wei ${ }^{2}$, przetłumaczonych na język polski poprzez język trzeci - niemiecki.

Przekład onimów jest trudnym zadaniem dla thumacza. Czasem ułatwia je zleceniodawca lub autor, np. w przypadku „Władcy Pierścieni” (zob. Jakiel i Jarosz, 2013) czy gry „Pokemony” (zob. Yin-Poole, 2011) określono dokładnie, że nazwy własne należy przełożyć tak, by odbiorca tekstu docelowego zrozumiał ich pierwotne znaczenie ${ }^{3}$. Często jednak tłumacz nie dostaje jasnych wytycznych i decyzję o strategii tłumaczeniowej podejmuje sam.

Autorka niniejszego artykułu występuje w roli tłumaczki-badaczki, która odnosi się do swojego działania, poddaje analizie własny wytwór i zachodzący w niej samej proces, stosując ogólnodostępne narzędzia językoznawcze. Zdaje

${ }^{1}$ Za krytyczne uwagi do tekstu dziękuję dr Izabeli Olszewskiej i dr. hab. Waldemarowi Czachurowi, prof. UW, oraz red. Mirosławie Buczyńskiej, za konsultacje sinologiczne Kamili Szuty.

${ }^{2}$ Zhang Wei, ur. 1956, chiński autor nowel i opowiadań, laureat wielu nagród literackich (więcej zob. http://www.homabooks.com/general/books/east_asia/china/1050.php\#author).

3, ,...] so other people overseas understand the original meaning we had from the Japanese. We try not to dilute the meaning" (Yin-Poole, 2011). 
się zatem wymykać z ram zakreślonych stwierdzeniem Dębskiego: „Metodologia badań translatorycznych musi wyciągnąc konsekwencje z faktu, że badacz nie ma bezpośredniego dostępu do procesów językowych w myśleniu tłumacza" (Dębski, 2006, s. 12). Niesie to jednak ze sobą określone ograniczenia i może utrudniać bezstronną analizę.

Celem prezentowanego opracowania jest zasygnalizowanie problematyki ukrytego w onimach i otwieranego przez nie językowego obrazu świata kultury wyjściowej oraz związanych z tym wyzwań dla tłumacza w sytuacji tłumaczenia pośredniego, czyli wykonywanego z innego tłumaczenia, a nie $\mathrm{z}$ oryginału.

\section{ONIMY I ADRESATYWY JAKO NOŚNIKI (TŁUMACZONEGO) JĘZYKOWEGO OBRAZU ŚWIATA}

W rozumieniu tekstu, a więc i jego przekładu, ważna jest semantyczna spójność tekstu. Gicala podkreśla za Labochą, że nie mówimy tu tylko o koherencji wewnętrznej tekstu, ale także o tym rodzaju spójności, „który tkwi nie w samych tekstach, ale w umysłach ludzi (w zdolnościach poznawczych) i ich wiedzy o świecie [...]" (Gicala, 2018, s. 43; zob. także Labocha, 2000). Patrząc na tę kaskadową konstrukcję, jaką jest thumaczenie (do tego w opisywanym tutaj przypadku tłumaczenie przez język trzeci), musimy mówić o spójności na wielu poziomach: 1) o wewnętrznej spójności semantycznej tekstu wyjściowego, 2) jego spójności z wiedzą o świecie odbiorcy (a więc o adekwatności doboru środków językowych do przedstawienia obrazu tego świata w tekście), 3) o spójności translatu z oryginałem, 4) o spójności translatu z wiedzą o świecie odbiorcy translatu, i wreszcie: 5) o spójności między pkt. 2 a 4, czyli takiej, która pozwala odbiorcy translatu zrozumieć oryginał, czytając produkt końcowy. W przypadku tłumaczenia przez język pośredni zachować należy spójność między językiem wyjściowym a pośrednim i między dwoma dodatkowymi światami.

Dostępne i stosowane przez thumaczy strategie pozwalają na przybliżenie lub oswojenie innego obrazu świata lub dostosowanie go do tego znanego odbiorcy (domestykacja), czy też na mobilizację odbiorcy do poznania kręgu kulturowego, z którego pochodzi tekst wyjściowy (egzotyzacja). Poprzez trafnie dobrane techniki przeniesienia thumacz zbliża odległe od siebie obrazy świata, redukuje to, co obce, do tego, co znane. Tłumaczenie to praktyka uczytelniania treści obcych dla określonej grupy kulturowej.

Zasadniczo w kognitywnej teorii przekładu należy przyjąć, że „przekład jest re-konstrukcją sceny, odtwarzającą wymiary obrazowania obecne w oryginale - zatem ekwiwalencja przekładu to ekwiwalencja obrazowania, a jednostką tłumaczeniową jest pojedynczy obraz [...]" (Gicala, 2018). Jednym z postulatów 
zorientowanej kognitywnie translatologii jest rozpatrywanie procesu thumaczenia jako „przekład[u] języków i światów, a nie wyłącznie jako językow[ego] transfer[u]" (Pieciul-Karmińska, 2007, s. 9). Za skopos w tak rozumianym procesie przekładu przyjąć więc należy adekwatny transfer obrazu do języka i kultury docelowej. Obraz wyjściowy i docelowy pozostają w nieustannym wzajemnym dialogu ${ }^{4}$ i muszą być poddawane nieustannej negocjacji dyskursywnej. Posługując się za Katanem (por. Katan, 1999) metaforą góry lodowej, Gicala pokazuje relacje między tym, co widoczne (tekstem), a tym, co niewidoczne — kulturą, tradycją, realiami języka wyjściowego, tożsamością, rytuałami (por. Gicala, 2018, s. 59). To w nich zanurzony jest widoczny dla nas tekst. To one tworzą ukazany w języku (standardowy lub nie) obraz świata i to je właśnie thumacz winien po pierwsze odnaleźć (czy raczej mieć świadomość ich istnienia i świadomie ich poszukiwać), po drugie — adekwatnie przenieść do języka docelowego.

Tam, gdzie wspomniane elementy, będące składowymi JOS-u (lub DOS-u $)^{5}$, korespondują z możliwym do rekonstrukcji w języku docelowym obrazem świata, kwestia ta nie podlega rozważaniom. Istotna staje się tam, gdzie występują elementy (lub całe obrazy) obce dla kultury docelowej, a więc inaczej reprezentowane w jej języku. To dla nich thumacz musi wybrać jednolitą strategię, najpierw jednak je zidentyfikować i zbadać 6 . Postrzeganie obcości w tekście thumaczonym opierać się może, jak wskazuje Lewicki, na odmienności językowej, kulturowej lub religijnej i aksjologicznej (Lewicki, 2000, s. 20). Jeśli w danym tekście obcość występuje, to jest ona aktywizowana w procesie odbioru przez czytelnika translatu (idealny tłumacz będzie ją w idealnym przypadku identyfikował), co dzieje się za pomocą sygnałów obcości, a więc jej potencjalnych nośników, które dadzą się zidentyfikować na poziomie jednostek tekstu oraz cech struktury tekstu. Lewicki wymienia osiem rodzajów jednostek tekstu będących potencjalnymi sygnałami obcości, a wśród nich nazwy własne i formy adresatywne (por. Lewicki, 2000, s. 45-49). Z jednej strony mogą one sygnalizować obcość. Z drugiej zaś są znakiem o wymiarze społecznie relewantnym (por. Kalverkämper, 1978, s. 35), tekstem, w którym zakodowany jest obraz świata danej kultury. W przypadku

\footnotetext{
${ }^{4}$ Gicala wprowadza rozumienie negocjacji językowej jako dialogu między profilem JOS (językowy obraz świata), który w tekście źródłowym ujawnia się jako JOS niestandardowy, a profilami JOS w języku i kulturze docelowej (por. Gicala, 2018).

${ }^{5}$ Na gruncie polskim teoria językowego obrazu świata (JOS) została rozwinięta i ugruntowana przez J. Bartmińskiego, S. Niebrzegowską, W. Chlebdę, rozszerzona jako teoria dyskursywnego obrazu świata (DOS) przez Czachura (2011).

${ }^{6}$ Tłumacz (jak i badacz JOS-u czy DOS-u w ujęciu przede wszystkim kontrastywnym) dysponuje oczywiście całym repertuarem metod i instrumentów językoznawczych, przede wszystkim z nurtu kognitywistycznego, od tych ściśle związanych z semantyką, jak jednostki prymarne i elementarne, słowa klucze, czy semantykę prototypu po Krytyczną Analizę Dyskursu (KAD).
} 
translatu to thumacz, decydując się na określoną formę nazwy własnej, dokonuje wyboru między „swojskim” a „obcym” (por. Rzetelska-Feleszko, 2006, s. 70-83).

Kompleksowa analiza antroponomastykonu w ujęciu lingwistyki kulturowej daje możliwość dekodowania obrazu relacji i podziałów społecznych, tradycji, historii czy nawet upodobań politycznych i wyznawanych wartości?

Imię, zwłaszcza w użyciu adresatywnym, zawiera informację o rodzaju relacji między uczestnikami komunikacji, w szerszym kontekście nie tylko o relacjach i dystansie między tymi konkretnymi uczestnikami aktu komunikacyjnego, lecz także o normach odnoszących się do dystansu i relacji interpersonalnych w danym kręgu kulturowym w ogóle. W nawiązaniu do A. Wilkonia (1970), H. Kalverkämpera (1978) i E. Rzetelskiej-Feleszko (2006) tak rozumiem funkcję społeczną nazw własnych, które są nośnikami doświadczeń i wartości, treści symboliczno-emocjonalnych oraz sposobu postrzegania świata. W tym sensie antroponimy są nośnikiem obrazu świata i niejako „oknem” na ten świat. W sytuacji transferu tekstu do kręgu kulturowego, w którym relacje te mają zupełnie inne tradycje, są inaczej budowane i pielęgnowane, a więc inaczej wyrażane w języku, tłumacz musi zastosować środki kompensujące, które oddadzą pożądany efekt. Już nawet tak bliskie sobie na pozór kultury, jak choćby polska i brytyjska, mają tu przecież różne normy i systemy (por. Biel, 2007, s. 516, 520). Język polski cechuje się dużymi możliwościami stopniowania dystansu (choćby przez deminutiva i augmentativa, czy też połączenie „,pani Basiu”), podczas gdy na przykład w angielskim skala tych możliwości jest mniejsza. W języku chińskim natomiast, który jest oryginalnym językiem omawianych opowiadań, występuje np. leksem Lao, który „pokazuje [...] respekt [...]. Więc [do] ludzi starszych od siebie albo braci właśnie mówimy używając »Lao«, czyli »starszy« [...] osoba, którą [autor] opisuje prawdopodobnie jest starsza, albo [...] jest wyżej postawiona [...]"8. W kulturze chińskiej możliwe jest sygnalizowanie różnicy pokoleń czy stanu lub pozycji społecznej przy użyciu środków leksykalnych. „Dla odróżnienia pokoleń męskich dodaje się przed nazwiskiem stary (老 Lăo), mały (小 Xiǎo). Taki sposób określania kogoś jest efektem odróżniającym dwa pokolenia, jak również jest wyróżnieniem sentymentalnym" (Zhongguo, 2014)9. Obie te cząstki, Lăo i Xiăo, występują w wersji niemieckiej analizowanego materiału.

Przeniesienie antroponimów chińskich na języki europejskie jest dodatkowo o tyle trudne, że w języku chińskim wszystkie imiona są znaczące, ich ważnym elementem jest też forma graficzna znaku (por. Galewska, 2019, s. 266-267),

\footnotetext{
${ }^{7}$ Więcej na temat imion jako nośników wartości patrz (Rzetelska-Feleszko, 2006, s. 9-30).

${ }^{8}$ Cytaty to transkrypcja fragmentu nagrań, które przekazała mi sinolog Kamila Szuty.

${ }^{9}$ Więcej na temat antroponimów chińskich patrz np. Zawadzki, 2015, s. 20 i n.
} 
która przy transkrypcji naturalnie zanika, a nawet gdyby tłumacz zdecydował się na jej pozostawienie, czy to w nawiasie czy w przypisie, byłaby dla większości czytelników znaczeniowo pusta. Konstatując za Galewską, „,[p]roblem polega [...] na tym, że każda nazwa własna w języku chińskim otwiera ścieżki mentalnego dostępu do wyjątkowo dużej liczby domen, podczas gdy ta sama nazwa transkrybowana nie otwiera właściwie żadnych domen dla użytkownika języka docelowego. W języku chińskim onimy oprócz znaczenia leksykalnego mają bogate znaczenia asocjacyjne" (Galewska, 2019, s. 267).

Tłumacząc poprzez język pośredni i zachowując w pamięci to, co powiedziano wyżej o wewnętrznej i wzajemnej semantycznej spójności tekstów i światów wyjściowych i docelowych w rozumieniu Gicali i Labochy, a także o specyfice onomastykonu chińskiego, należy zwrócić szczególną uwagę na zawarty w omawianych tutaj artefaktach językowych obraz społeczeństwa wiejskiego w Chinach końca XX w.

W kontekście omawianego problemu skoposem jest taki transfer onimów chińskich do języka polskiego (za pośrednictwem języka niemieckiego), który odda ich wszystkie funkcje, przede wszystkim zaś socjologiczną (społeczną) i ekspresywną (por. Wilkoń, 1970, s. 89-95; 105-112), pokazując różnice generacyjne i społeczne uczestników komunikacji (bohaterów analizowanych opowiadań).

\section{ONIMY W TŁUMACZENIU}

Onimom w tłumaczeniach poświęcono w literaturze przedmiotu już wiele uwagi, omawiając je zarówno w kontekście ich przekładalności w ogóle (a także zasadności terminu „tłumaczenie” w odniesieniu do nazw własnych) (np. Kalverkämper, 1978), ich przekładalności i ewentualnych strategii/technik przekładu w literaturze dla dzieci czy fantasy (np. Jakiel i Jarosz, 2013; Kromp, 2008), jak i ich treści kulturowej i socjolingwistycznej (np. Cataldi, 2009; Kosyl, 1983; Thurmair, 2002; Wilkoń, 1970). Tak bogata tradycja badawcza nie wymaga tu szczegółowego omówienia, lecz tylko ogólnego przypomnienia dokonanych ustaleń.

W kontekście literackich tekstów tłumaczonych na inne języki można wyróżnić za Lewickim (2000) trzy grupy nazw własnych, obecnych w translacie ${ }^{10}$ :

1) w oryginalnym brzmieniu, nieadaptowane - powodują egzotyzację tekstu,

2) odczuwane jako obce, adaptowane fonetycznie,

3) popularne w obu kulturach, nieodczuwane jako obce (por. Lewicki, 2000, s. 46 i n.).

${ }^{10}$ U Lewickiego na przykładzie pary języków rosyjski/polski. 
W omawianym materiale grupa trzecia nie występuje w ogóle, niemal wszystkie antroponimy (poza Minzi $\rightarrow$ Gabi) należą do grupy pierwszej, adaptowanej graficznie.

Tematem wielu badań stały się także techniki i strategie przeniesienia ${ }^{11}$ nazw własnych do tekstu w języku docelowym. W naszym odczuciu wyboru tych technik $^{12}$ należy zawsze dokonywać dla konkretnej nazwy, mając na względzie jej najważniejszą funkcję w tekście. Onomastykon każdego utworu literackiego nie jest raczej jednorodny, ale składa się zarówno z nazw znaczących, jak i pustych, rzeczywistych i fikcyjnych, trudno zatem traktować je jednakowo, poszczególną technikę należy jednak podporządkować skoposowi i strategii nadrzędnej.

W zależności od rodzaju onimów w tekście wyjściowym oraz ustalonego celu nadrzędnego tłumacz może posłużyć się (patrz także Jakiel i Jarosz, 2013, s. 98 i n.):

1) formą paralelną (Hengst, 2005, s. 82 i n.) (Paul $\rightarrow$ Pawet, pamiętać jednak należy o tym, że mamy tutaj możliwe przesunięcie, Paulus w języku łacińskim jest imieniem mówiącym (łac. paulus ‘mały, drobny’), w języku polskim imieniem pustym),

2) reprodukcją (Hejwowski, 2004, s. 76-85),

3) thumaczeniem funkcjonalnym lub quasi-funkcjonalnym (substytucją) (Debus, 2002, s. 97; por. Hejwowski, 2004, s. 38-47),

4) tłumaczeniem bezpośrednim elementów transparentnych semantycznie ${ }^{13}$ (por. Debus, 2002, s. 97).

Czy zastosowane w badanym tłumaczeniu techniki umożliwiają odbiorcy tekstu docelowego odczytanie zakodowanego w onimach obrazu świata kultury wyjściowej? Czy dla odbiorcy tekstu w języku polskim czytelna jest pierwotna funkcja społeczna chińskich antroponimów?

Starając się odpowiedzieć na te pytania, nie można stracić z oczu pewnych ograniczeń, które thumacz napotyka w swojej pracy, jak w tym konkretnym przypadku brak znajomości języka wyjściowego i brak dostępu do oryginału, co uniemożliwiło konsultację sinologiczną. Niemal zawsze ograniczeniem jest duża decyzyjność redakcji i wydawnictwa.

${ }^{11}$ Termin uważam za bardziej adekwatny niż „przekład” czy „tłumaczenie” nazw własnych (por. Kalverkämper, 1978, s. 86 i n.).

${ }^{12}$ Na poziomie strategii przeniesienia nomina propria tłumacz musi zdecydować o najważniejszej dla tłumaczenia tekstu funkcji nazw własnych, co ma znaczenie w sytuacji nazw znaczących (imiona mówiace/speaking names/redende lub sprechende Namen).

${ }^{13} \mathrm{~W}$ tej grupie uwzględniam także thumaczenie synonimiczne w ujęciu H. Kautza (por. Kautz, 2000, s. 131) i syntagmatyczne w ujęciu K. Hejwowskiego (por. Hejwowski, 2004, s. 76-85), które R. Jakiel i J. Jarosz rozumieją jako osobne techniki (por. Jakiel i Jarosz, 2013, s. 98). 


\section{KORPUS, ANALIZA SPÓJNOŚCI TEKSTU NIEMIECKIEGO I TRANSLATU}

Analizowany zbiór „Baummoos pflücken” składa się z dziesięciu opowiadań napisanych w latach 1983-1987.

Tabela 1. Zestawienie tytułów opowiadań i ich tłumaczeń

\begin{tabular}{|l|l|}
\hline \multicolumn{1}{|c|}{ Tytuł niemiecki } & \multicolumn{1}{c|}{ Tytuł polski } \\
\hline Der Kristallsee & Kryształowe jezioro \\
\hline Der Schneesturm am Meer & Śnieżyca nad morzem \\
\hline Der Pfeifenkopf & Cybuch \\
\hline Die Tabakblätter & Liście tytoniu \\
\hline Baummoos pflücken & Zbieranie porostów \\
\hline Was heißt „,aufgeregt sein“? & Co to jest „ekscytacja”? \\
\hline Die fantastische Nacht des Regens & Fantastyczna deszczowa noc \\
\hline Minzi aus dem herbstlichen Wald & Gabi z jesiennego lasu \\
\hline Das Lächeln der Eiche & Dąb się śmieje \\
\hline Die auf dem Boden verstreut liegenden Blätter & Kobierzec jesiennych liści \\
\hline
\end{tabular}

Wersję polską tekstów opublikowało Wydawnictwo Adam Marszałek jako część serii wydawniczej składającej się z siedmiu tytułów ${ }^{14}$. Jest ona tłumaczeniem z języka niemieckiego, w którym jednak nigdy nie wydano powyższych opowiadań, co wpłynęło znacząco na jakość przekazanego materiału — nie są to teksty gotowe do druku, z pewnością bez korekty redaktorskiej. Każde opowiadanie jest osobnym tekstem, nie tworzą one cyklu i nie łączą się w żaden sposób ani miejscem, ani bohaterami, ani akcją. Widać w tym materiale niespójność wynikającą z pracy kilku thumaczy nad tekstem niemieckim ${ }^{15}$, bardzo prawdopodobne wydaje się, że thumacze zmieniali się nawet w obrębie jednego tekstu.

Przypuszczenie to potwierdza analiza stylometryczna, wykonana na korpusie tekstów niemieckich za pomocą narzędzia WebSty ${ }^{16}$ (wersja multilingwalna). Największe podobieństwo wykazuje para tekstów: „Baumoos pflücken” i „Der Kristallsee", które kształtuje się na poziomie 0,27 , najmniejsze zaś (na poziomie 0,10 )

${ }^{14}$ Seria obejmuje następujące zbiory: „Lis i wino”, „Zakątki Chin. Sekrety pola kukurydzy”, „Jesienny gniew i inne opowiadania”, „Ratuj artystę!”, „Winogrona w deszczu jesiennym”, „Morski wiatr”, „Zbieracz porostów”.

${ }^{15}$ Ustna informacja przekazana autorce przez redaktorkę Kingę Sołowiej, rozmowa telefoniczna $\mathrm{z}$ czerwca $2018 \mathrm{r}$.

${ }^{16}$ Narzędzie dostępne pod adresem: http://ws.clarin-pl.eu/webstyml.shtml (dostęp: 9.09.2019). 
wykazują teksty „Der Kristallsee” i „Die auf dem Boden verstreut...”. Warto w tym miejscu podkreślić, że przy analizie stylometrycznej przeprowadzonej dla gotowego translatu wartości współczynnika podobieństwa są wyższe. Największe podobieństwo w zakresie autorstwa wykazują według tej analizy teksty „Kobierzec...” i „Fantastyczna..." $i$ jest to podobieństwo na poziomie 0,44 . Najmniej podobne są teksty „Śnieżyca...” i „Fantastyczna...” — ich wskaźnik to 0,11.

Z tekstów wyekscerpowano 46 antroponimów, uwzględniono wszystkie występujące imiona, różne warianty pisowni - nawet jeśli ewidentnie wynikające z błędu — ujęto jako odrębną jednostkę. Tylko 6 to imiona żeńskie, a 40 męskie, odnoszą się one do 26 desygnatów męskich i 6 żeńskich.

Występujące w zbiorze antroponimy (niemieckie i polskie) prezentuje poniższa tabela, uwzględniająca ich podział na imiona męskie (ð̋) i żeńskie (q):

Tabela 2. Zestawienie antroponimów niemieckich i ich odpowiedników polskich w badanym materiale

\begin{tabular}{|c|c|c|c|}
\hline Tekst & $\begin{array}{c}\text { Antroponim } \\
\text { w tekście niemieckim }\end{array}$ & $\begin{array}{c}\text { Ekwiwalent } \\
\text { w tekście polskim }\end{array}$ & Uwagi \\
\hline $\begin{array}{l}\text { „Kryształowe } \\
\text { jezioro" }\end{array}$ & 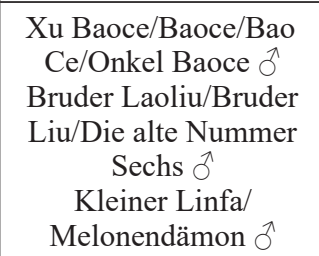 & $\begin{array}{l}\text { Xu Baoce/Baoce/ } \\
\text { Wujek Baoce } \\
\text { Brat Liu/Stary Liu } \\
\text { Mały Linfa } \\
\text { Arbuzowy Demon }\end{array}$ & Brat Liu \\
\hline $\begin{array}{l}\text { „Śnieżyca nad } \\
\text { morzem" }\end{array}$ & $\begin{array}{c}\text { Jin Bao/Panther }{ }^{\lambda} \\
\text { der alte Gang } \delta^{\lambda}\end{array}$ & $\begin{array}{c}\text { Jin Bao/Pantera } \\
\text { Stary Gang }\end{array}$ & \\
\hline „Cybuch” & 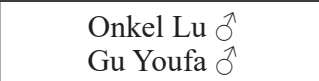 & $\begin{array}{l}\text { Wujek Lu } \\
\text { Gu Youfa }\end{array}$ & \\
\hline „Liście tytoniu” & $\begin{array}{c}\text { Nianxi/Nianxu } ð \\
\text { Der hinkende Laosi/ } \\
\text { Der humpelnde Laosi/ } \\
\text { Onkel Si } \delta\end{array}$ & $\begin{array}{c}\text { Nianxi } \\
\text { Kulejący Si/Wujek Si / } \\
\text { Si/Kuśtykający Si }\end{array}$ & $\begin{array}{l}\text { Kulejący Si - } \\
\text { jedno wystapie- } \\
\text { nie w tekście }\end{array}$ \\
\hline $\begin{array}{l}\text { „Zbieranie poro- } \\
\text { stów" }\end{array}$ & $\begin{array}{l}\text { Songsong } 9 \\
\text { der alte } \mathrm{Lu} \hat{0} \\
\text { Dazhuang } \hat{0} \\
\text { Xiaoban } \varnothing\end{array}$ & $\begin{array}{l}\text { Songsong } \\
\text { Stary Lu } \\
\text { Dazhuang } \\
\text { Xiaoban }\end{array}$ & \\
\hline $\begin{array}{l}\text { "Co to jest »ekscy- } \\
\text { tacja«?" }\end{array}$ & 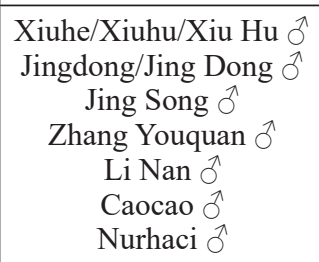 & $\begin{array}{c}\text { Xiuhu } \\
\text { Jingdong/Jing Dong } \\
\text { Jingsong } \\
\text { Zhang Youquan } \\
\text { Li Nan } \\
\text { Caocao } \\
\text { Nurhaci }\end{array}$ & $\begin{array}{l}\text { Jingdong/Jing } \\
\text { Dong - pozo- } \\
\text { stawiono do } \\
\text { decyzji redakcji }\end{array}$ \\
\hline
\end{tabular}




\begin{tabular}{|c|c|c|c|}
\hline $\begin{array}{l}\text { „Fantastyczna } \\
\text { deszczowa noc” }\end{array}$ & $-/-$ & & \\
\hline $\begin{array}{l}\text { "Gabi z jesiennego } \\
\text { lasu" }\end{array}$ & $\begin{array}{c}\text { Minzi/Mizhi } q \\
\text { Wushu (der fünftälteste } \\
\text { Onkel) } \hat{\sigma} \\
\text { Yongsheng } \widehat{\partial} \\
\text { Huisheng } \hat{\sigma}\end{array}$ & $\begin{array}{c}\text { Gabi/Ghabi/Grabi } \\
\text { starsza siostra } \\
\text { Wushu } \\
\text { Yongsheng } \\
\text { Huisheng }\end{array}$ & $\begin{array}{l}\text { Wushu w wer- } \\
\text { sji niemieckiej } \\
\text { wyjaśniono } \\
\text { bezpośred- } \\
\text { nio w tekście, } \\
\text { w wersji polskiej } \\
\text { w przypisie jako } \\
\text { [przyp. tłum.] }\end{array}$ \\
\hline „Dąb się śmieje” & 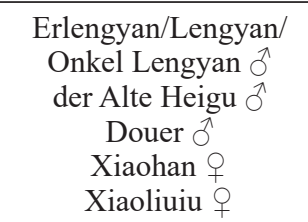 & $\begin{array}{c}\text { Erlengyan/Wujek } \\
\text { Lengyan } \\
\text { Stary Heigu/Heigu } \\
\text { Douer } \\
\text { Xiaohan } \\
\text { Xiaoliuiu }\end{array}$ & $\begin{array}{c}\text { "Wujek Lengyan" } \\
\text { w użyciu adresa- } \\
\text { tywnym }\end{array}$ \\
\hline $\begin{array}{l}\text { „Kobierzec jesien- } \\
\text { nych liści” }\end{array}$ & Xiao Xiao $q$ & Xiao Xiao & \\
\hline
\end{tabular}

Powyższe zestawienie ukazuje, jak różne techniki zastosował tłumacz w przeniesieniu badanego antroponomastykonu na język polski.

\section{ZASTOSOWANE TECHNIKI PRZENIESIENIA ANTROPONIMÓW Z UWZGLĘDNIENIEM ICH FUNKCJI SPOŁECZNEJ}

Pierwszym i oczywistym sygnałem obcości, pokazującym, że właśnie w antroponimach może kryć się inny świat, który otwiera się przed thumaczem, była niekonsekwencja w przeniesieniu imion na język niemiecki, np. różny ich zapis: Nianxi vs Nianxu, Baoce vs Bao Ce. Dodatkowo w opowiadaniu „Kryształowe jezioro” w odniesieniu do tej samej osoby zamiennie występowały onimy: Bruder Laoliu (Brat Laoliu) / Bruder Liu (Brat Liu) / Die alte Nummer Sechs (Stary Numer Sześć). Oczywiste więc stało się, że zarówno Lao, jak i Liu w języku chińskim są apelatywami. Ponadto cząstka Lao pojawia się też w innych imionach, czasem zamiennie z Onkel/Wujek (Laosi/Onkel Si $\rightarrow$ Laosi/Wujek Si). O znaczeniu leksemu Lao piszę wyżej. W tłumaczonych opowiadaniach pojawia się także wspominana wyżej cząstka Xiao (patrz tab. 2) w imionach żeńskich. Te środki leksykalne występują w badanym materiale w odniesieniu do 8 postaci męskich i 5 postaci żeńskich.

Drugim celem, po stworzeniu spójnego zbioru tekstów w języku polskim, stał się więc taki przekład onimów, który odda możliwie najlepiej ich funkcję społeczną, zaznaczenie starszeństwa i ewentualnego respektu dla danej osoby.

W polszczyźnie tradycyjnie były w użyciu środki zaznaczające status i wiek danej osoby: leksykalne (panna/panienka/pani vs panicz/pan przed imieniem 
lub nazwiskiem) i słowotwórcze (Nowakowa/Nowakówna, Skarga/Skarżanka). Możliwości takie mają też oczywiście inne języki (wł. signorina/signora, fr. mademoiselle/madame), w tym niemiecki. Dość powszechne (w RFN usunięte z użycia w języku urzędowym dopiero w latach 80 . ubiegłego stulecia, w NRD kilka lat później) było stosowanie leksemu Fräulein, który podobnie jak polskie panna sygnalizuje stan cywilny i wiek kobiety, do której się zwracamy. Rozróżnienie to, tak powszechnie stosowane jeszcze niedawno, dotyczy wyłącznie kobiet. Stosowane wprawdzie w latach 80 . XX w. wspomniane leksemy nie są jednak paralelne do chińskich i nie mogły w związku z tym wystąpić w przekładzie. Zaproponowane leksomorfemy ${ }^{17}$ nie oddają istoty relacji społecznych, zawartych w leksemie Lao czy Xiao, siłą rzeczy więc nie występują one także w thumaczeniu niemieckim. W wersji niemieckiej tłumacze zdecydowali się na thumaczenie bezpośrednie transparentnej semantycznie cząstki Lao, co ciekawe technikę tę zastosowano wyłącznie dla imion męskich, paralelna żeńska cząstka Xiao nie jest w żadnym wystąpieniu przeniesiona na polski, pozostałe antroponimy przeniesiono techniką reprodukcji.

Leksem Lao został przełożony jako Onkel $\rightarrow$ Wujek (4 wystąpienia), Bruder $\rightarrow$ Brat (1 wystąpienie) i Alt $\rightarrow$ Stary (4 wystąpienia). W większości przypadków konsekwentnie do niemieckiej wersji, w dwóch (w opowiadaniu „Dąb się śmieje” i „Kryształowe jezioro”) antroponimy w wersji polskiej przełożono na język polski za pomocą mniejszej liczby ekwiwalentów: Bruder Laoliu / Bruder Liu / Die Alte Nummer Sechs $\rightarrow$ Brat Liu, Stary Liu i Erlengyan/Lengyan / Onkel Lengyan $\rightarrow$ Erlengyan / Wujek Lengyan, co w obliczu chaotycznego przekładu na język niemiecki znacząco wpłynęło na poprawę spójności tekstów.

Czy wujek/brat/stary rzeczywiście oddają starszeństwo oraz szacunek w stosunku do osoby, do której się zwracamy? Czy kreują te same obrazy? W tym wypadku w centrum zainteresowania jest wyłącznie wersja polska tekstu, ponieważ jednak powstała ona na bazie tłumaczenia niemieckiego, leksemy te zostaną zaprezentowane w obu językach. Poza oznaczeniem pokrewieństwa zarówno wujek, jak i brat używane są w znaczeniu:

„Mann [bekannter] männlicher Erwachsener” (pol. mężczyzna [znajomy] dorosty ptci męskiej) (Dudenredaktion, b.d.), co ciekawe: z kwalifikatorem, język dzieci”. W polszczyźnie dzieci używają tego zwrotu podobnie — w stosunku do starszych od siebie mężczyzn, niekoniecznie spokrewnionych, dobrych znajomych rodziców. Onkel w niemczyźnie ma także konotacje negatywne (,der komische Onkel”, pol. dziwny facet), podczas gdy w polszczyźnie wyrażać może

${ }^{17}$ Niem. Höflichkeits-Lexomorphem, pol. leksomorfem wyrażający uprzejmość, termin za Ackermannem i Kalverkämperem (Ackermann, 2018, s. 64; Kalverkämper, 1978, s. 135 i n.). 
także poufałość (w formie „wujaszek”, „wujcio”), nie występuje raczej w znaczeniu negatywnym.

Bruder i brat to: „Mitmensch; jemand, mit dem sich jemand [freundschaftlich] verbunden fühlt”, pol. ‘bliźni; ktoś, z kim czuje się [przyjacielsko] związanym' (Dudenredaktion, b.d.), „Kamerad, Genosse, enger Freund”, pol. 'kolega, towarzysz, bliski przyjaciel' (Wahrig 1986/91, s. 300), podobnie w polszczyźnie: 'człowiek, z którym jest się związanym przyjaźnią, bliskimi stosunkami: a) o człowieku bliskim komuś ze względu na wspólne przeżycia [...] pochodzenie społeczne, narodowe itp.; o koledze, współtowarzyszu w służbie' (SJPDor).

Zarówno dla leksemu wujek, jak i brat należałoby wykonać analizę ukrytego w nich JOS, co znacznie przekracza ramy tej pracy ${ }^{18}$. Opracowanie Tokarskiego dla hasła „,brat” w drugim wariancie znaczeniowym w ramach ,Słownika stereotypów i symboli ludowych" zdaje się potwierdzać, że wybór tego leksemu przez tłumacza był właściwy (zob. Tokarski, 1980).

Można powiedzieć, że znaczenia niem. alt i pol. stary się pokrywają. W przedmiotowym zbiorze najważniejsze jest użycie familiarne, które potwierdzają w niemczyźnie słowniki Wahriga (1986/91, s. 956) i stylistyczny (Drosdowski i Eckey, 1988, s. 50), w polszczyźnie słownik Doroszewskiego w drugim wariancie znaczeniowym. Dane te odnoszą się do użycia w wołaczu, w formach adresatywnych (dla polszczyzny w użyciu rzeczownikowym), dla przymiotnika podkreśla się doświadczenie, długie życie (SJPDor). Odpowiadałoby to semom 'respekt', 'starszeństwo' cząstki Lao w chińskim.

Warte podkreślenia jest też imię Gabi, w języku niemieckim Minzi (opowiadanie „Gabi z jesiennego lasu”), które ze względu na występującą w tekście grę słów zostało przełożone funkcjonalnie. W języku niemieckim tłumacz zdecydował się na adaptację fonetyczną, a grę słów wyjaśnił w nawiasie ${ }^{19}$. W języku polskim wybrano odpowiednik funkcjonalny, umożliwiający oddanie zabawy słowem Gabi/Grabi. Odpowiednik pochodzi wprawdzie w wersji niemieckiej z obszaru jedzenia, w polskiej zaś z obszaru narzędzi, ale jest krótki, wymowny i pozostaje w kręgu słownictwa rolniczego i ogrodniczego, zrozumiałego dla przeciętnego odbiorcy polskojęzycznego.

${ }^{18}$ Analiza JOS obejmuje różne typy danych: dane systemowe, tekstowe, pozyskiwane zwykle za pomocą ankiet dane przyjęzykowe (wywołane) (por. Niebrzegowska-Bartmińska, 2017, s. 18). Zinken (2016, s. 336) postuluje włączenie do tej matrycy interakcji codziennych. Nie było możliwe przeprowadzenie ankiet dotyczących użycia obu leksemów w latach 1980-1990, dlatego też opieram się na pierwszym typie danych. Utrudnia to uwzględnienie istniejących w polszczyźnie i niemczyźnie różnic między znaczeniem leksykalnym a użytkowym omawianych jednostek.

19 „Mizhi bedeutet Reisfett” (przypis w materiale przekazanym w pliku Word). Reisfett to dosłownie „ryżowy tłuszcz”, określenie stosowane również jako niemiecki odpowiednik azjatyckiej potrawy Nasi Lemak. 


\section{PODSUMOWANIE I WNIOSKI}

Rozdzielenie tekstów między kilku tłumaczy w pierwszym etapie tłumaczenia naruszyło z całą pewnością pierwotną spójność każdego z pojedynczych tekstów i całego zbioru. Nadrzędnym celem thumaczki było przywrócenie spójności w polskiej wersji materiału, na co mogła wpłynąć odpowiednio dobrana strategia translacji onimów. Istotne było przekazanie wszystkich pierwotnych funkcji występujących w tekście antroponimów, zwłaszcza ich funkcji społecznej.

Prezentowane wyżej wyniki analizy stylometrycznej zdają się także potwierdzać przypuszczenie i informację z wydawnictwa, że teksty na język niemiecki tłumaczyło kilka osób, co uwidoczniło się także przy przekładzie onimów. Należy gwoli sprawiedliwości zaznaczyć, że i w wersji polskiej zostawiono wiernie i konsekwentnie oddane onimy, poprawiając tylko oczywiste usterki (literówki, pisownia łączna/rozłączna) ${ }^{20}$. Wyniki dla translatu pokazują natomiast, że po pierwsze sygnał tłumacza jest dość silny — widoczny jest wyraźny ślad tłumacza (przynajmniej w przypadku analizowanych tu tekstów), po wtóre, współczynnik spójności tekstu docelowego jest dużo wyższy, na co bez wątpienia miał wpływ adekwatny przekład onimów.

Badanie występujących w wersji niemieckiej onimów: der Alte Heigu, der alte $L u^{21}$ oraz Onkel Si pozwala przypuszczać, że między tekstem chińskim a niemieckim nastąpiła leksykalizacja Lao. Mogli to więc być Laoheigu i Laolu oraz np. Laosi, chociaż Onkel pojawia się w odniesieniu do bohatera o imieniu Erlengyan i jest to imię w niemieckim tekście wykorzystane w kilku miejscach jako Onkel Lengyan, co sugeruje, że Er ma podobną funkcję społeczną jak Lao.

Tylko w przypadku jednego imienia żeńskiego nie użyto wskazującego na różnice społeczne Xiao, wszystkie inne leksem ten zawierają, a zatem nie został on zleksykalizowany ani w niemieckiej, ani w polskiej wersji.

W przypadku imion męskich środek leksykalny Lao dotyczy 8 imion (20\%), gdyby jednak uwzględnić imiona tylko w odniesieniu do osób, licząc różnie zapisane antroponimy jako jeden antroponim (np. Laoliu / Brat Liu), to otrzymujemy 26 desygnatów, do których odnoszą się męskie imiona i tym samym odsetek ten wzrasta do 33\%. Liczba i użycie antroponimów pokazuje, że społeczeństwo chińskie wciąż silnie trzyma się tradycji kodowania w imionach i formach adresatywnych relacji międzyludzkich i podkreśla w ten sposób istniejące między uczestnikami komunikacji różnice generacyjne i społeczne.

${ }^{20}$ Zgodnie ze wskazówką redaktor: „Oczywiście chińskie zwroty (zapewne będą to imiona, ewentualnie miejsca) zostają nie zmienione” (e-mail z 08.06.2018, odpowiedź na prośbę tłumacza o wytyczne dla nazw własnych w całym cyklu, pisownia oryginalna).

${ }^{21}$ Pisownia zgodnie z tekstem niemieckim — raz wielką, raz małą literą. 
Analiza kwantytatywna badanego zbioru wykazała, że niemal 87\% antroponimów to imiona męskie. Wskazuje to na dominację mężczyzn w społeczeństwie chińskim w rejonach wiejskich w drugiej połowie ubiegłego stulecia. Antroponimy żeńskie występują w połowie analizowanych opowiadań (5), w większości jednak to mężczyźni są głównymi bohaterami. Tylko w trzech opowiadaniach (30\%) główną bohaterką jest kobieta, jednym z tych opowiadań jest „Fantastyczna deszczowa noc", w którym bohaterka pozostaje bezimienna.

Obserwacja zastosowanych technik przeniesienia onimów nasuwa następujące pytania:

1. Czy nie byłoby bardziej adekwatne zastosowanie ekwiwalentu Wujek także w opowiadaniu „Kryształowe jezioro” (a więc Wujek Liu zamiast Brat Liu)? Wydaje się, że thumacz dobrze wybrał ekwiwalent Bruder $\rightarrow$ Brat, ponieważ w tym opowiadaniu mamy dwóch zbliżonych wiekiem bohaterów, których łączą wspólne przeżycia, praca i status społeczny. Występujący w tym opowiadaniu chłopiec, Mały Linfa, nie zwraca się do Liu nigdy bezpośrednio, a różnica generacyjna między nim a resztą bohaterów została zaznaczona przydawką mały, w kontrze do stary. Ważna wydaje się tutaj kwestia perspektywizacji — czy mówi narrator, czy też bohaterowie między sobą, co należałoby także uwzględnić.

2. Czy przymiotnik stary w funkcji przydawki przed imieniem nie jest nadwyżką tłumaczeniową (a więc błędem)?

$\mathrm{Z}$ jednej strony, jak wspomniano wyżej, zastosowanie stary jako odpowiednika niemieckiego Onkel jest w analizowanych tekstach trafnym wyborem, pokazuje szacunek i doświadczenie, w użyciu rzeczownikowym stary używany jest familiarnie. Polskie „stary, ale jary” (niem. „alt, aber rüstig”) pokazuje łączone ze starszym wiekiem wytrenowanie, siłę fizyczną, z drugiej strony „stare” jest „to, co [...] dawne, nieaktualne” (SJPDor), ktoś ,,wiekowy, w zaawansowanym wieku, leciwy, sędziwy [...]" (SJP PWN). Wydaje się jednak, że nie jesteśmy w stanie uniknąć różnego rozumienia leksemu alt (pol. stary), a kontekst dostatecznie wskazuje na wybrany przez autora wariant znaczeniowy.

3. Czy nie korzystniej dla tekstu było zostawić imiona transliterowane? (Laoliu, Laosi)?

Patrząc na pisownię np. imienia Baoce vs Bao Ce czy Jingdong vs Jing Dong, należałoby do zdecydowanej większości występujących w badanym zbiorze antroponimów zastosować przede wszystkim technikę tłumaczenia elementów transparentnych semantycznie — zarówno Bao, jak i Jing oraz wspomniane już wielokrotnie żeńskie Xiao mogłyby wówczas przekazać więcej informacji na temat relacji społecznych w Chinach.

Pozostawienie onimów w wersji tylko zaadaptowanej graficznie pozwoliłoby mówić o jednolitej strategii translatorskiej dla całości zbioru, nie dałoby jednak możliwości przekazania funkcji społecznej chińskich antroponimów. Trudno 
wymagać od thumacza takiej ingerencji w sytuacji tłumaczenia przez język trzeci, w którym często tłumacz powiela błędy, popełnione przez poprzednika i bez jasnych wytycznych ze strony redaktora, które powinny być jednolite dla całej serii. Wydaje się również, że dla czytelnika polskiego wszystko to, co zostało tu przedstawione, pozostaje na poziomie informacji „podskórnej”, nie odczuwa on tych niekonsekwencji, których tłumacz jest świadom.

W wersji polskiej tekstu przede wszystkim usunięto najbardziej oczywiste błędy, na przykład wprowadzono jednolite imiona dla tych samych postaci (m.in. ujednolicono zapis, w jednym przypadku zostawiono podwójną pisownię do decyzji redaktor tomu). Zlikwidowano także dublety: Bruder Laoliu został po prostu Bratem Liu, Laosi - Wujkiem Si.

Praca z onimami, poszukiwanie dla nich ekwiwalentów i analiza pokazują, że antroponimy i formy adresatywne są w swej funkcji społecznej nośnikiem językowego obrazu świata i „oknem na świat” zamkniętym w języku. Bardzo wyraźnie wskazują one na role i relacje społeczne oraz na relacje i różnice społeczne między uczestnikami komunikacji. Język chiński leksykalizuje te różnice określonymi przedrostkami (Lao-, Er-, Xiou-), takich lustrzanych możliwości nie ma ani język niemiecki, ani polski.

W podejściu kognitywnym do przekładu zaproponowana przez Gicalę metafora góry lodowej (por. Gicala, 2018, s. 59), zwłaszcza w konkretnym przypadku omawianych tu onimów, wydaje się uzasadniona. W badanym przykładzie antroponimy to tylko wierzchołek tej góry, jej niewidoczna dla nas podstawa to cały kontekst społeczno-kulturowy nadany opowiadaniom przez tradycję i zwyczaje w Chinach w latach 80. XX w.

Omówiona powyżej problematyka adekwatnego kulturowo przeniesienia onimów w tłumaczeniu przez język trzeci z materiału ułomnego, bez dostępu do tekstu oryginalnego, w sytuacji presji czasowej i budżetowej to tylko jedno $z$ wielu wyzwań, z którymi tłumacz tekstów literackich musi się zmierzyć. Zastosowane w omawianym materiale techniki należy uznać za dobrane właściwie dla zamierzonego celu i możliwości. Między innymi te zabiegi z pewnością wpłynęły na znaczną poprawę koherencji tłumaczonego zbioru (patrz analiza stylometryczna niemieckich tekstów wyjściowych i wersji polskiej).

Praca na dalekim od doskonałości materiale i przez język trzeci nie jest na rynku thumaczeniowym niestety niczym niezwykłym, zwłaszcza w odniesieniu do języków tzw. rzadkich. Włączenie osiągnięć badawczych onomastyki kulturowej do kanonu kształcenia tłumaczy w warunkach akademickich jest w tym świetle pilnym dezyderatem. 


\section{ŹRÓDŁO ONIMÓW}

Wei, Z. (2019). Zbieracz porostów. Tłumaczenie: Edyta Grotek. Toruń: Time Marszałek Group.

\section{LITERATURA}

Ackermann, T. (2018). Grammatik der Namen im Wandel: Diachrone Morphosyntax der Personennamen im Deutschen. Berlin-München-Boston: De Gruyter.

Biel, Ł. (2007). Językowy obraz relacji interpersonalnych: różnice w wyrażaniu dystansu psychologicznego i społeczego w języku angielskim i polskim [A linguistic depiction of interpersonal relations: differences in expressing psychological and social distance in English and Polish.]. W: A. Szczęsny, K. Hejwowski (red.), Językowy obraz świata w oryginale i przektadzie: materialy z konferencji naukowej zorganizowanej przez Instytut Lingwistyki Stosowanej Uniwersytetu Warszawskiego w Warszawie w dniach 25-27 listopada 2005 (s. 513-522). Siedlce: Instytut Lingwistyki Stosowanej, Uniwersytet Warszawski.

Cataldi, A. (2009). Nieprzekładalność słownictwa a zawartość podtekstu kulturowego [The untranslatability of vocabulary and content with cultural overtones]. Rocznik Przekładoznawczy. Studia Nad Teoria, Praktyka i Dydaktyka Przektadu, 5, 69-81.

Czachur, W. (2011). Diskursive Weltbilder im Kontrast. Linguistische Konzeption und Methode der kontrastiven Diskursanalyse deutscher und polnischer Medien. Wrocław: Atut Oficyna Wydawnicza.

Dębski, A. (2006). Translatologia. Podstawowe problemy, stan i perspektywy badań, zainteresowania badaczy [Translatology. Basic problems, research status and perspectives, researchers' interests]. Rocznik Przektadoznawczy. Studia nad Teoria, Praktyka i Dydaktyka Przektadu, 2, 11-39. https://doi.org/10.12775/RP.2006.001

Debus, F. (2002). Namen in den literarischen Werken: (Er-)Findung — Form - Funktion. Stuttgart: Franz Steiner Verlag.

Drosdow ski, G., Eckey, W. (1988). Duden Stilwörterbuch der deutschen Sprache: Die Verwendung der Wörter im Satz. Mannheim: Dudenverlag.

Dudenredaktion (b.d.). Duden online. https://www.duden.de

Galewska, K. (2019). Tłumaczenie chińskich nazw własnych w ujęciu kognitywnym [The translation of Chinese proper names: A cognitive approach]. Onomastica, 63, 263-278.

Gicala, A. (2018). Przekładanie obrazu świata. Językowy obraz świata w przekładzie artystycznym [Translating the image of the world. The linguistic image of the world in artistic translation]. Kraków: Universitas.

Hejwowski, K. (2004). Kognitywno-komunikacyjna teoria przektadu [A cognitive-communicative theory of translation]. Warszawa: Wydawnictwo Naukowe PWN.

Hengst, K. (2005). Wege der Poetonomastik. W: A. Brendler, S. Brendler (red.), Namenforschung morgen. Ideen, Perspektiven, Visionen (s. 81-86). Hamburg: Baar-Verlag.

Jakiel, R. i Jarosz, J. (2013). Zum Gebrauch der Übersetzungstechniken bei der Wiedergabe der Eigennamen in der deutschen Translation des Romans von J.R.R. Tolkien „The Lord of the Rings". Germanica Wratislaviensia, 137(3471), 95-112.

Kalverkämper, H. (1978). Textlinguistik der Eigennamen. Stuttgart: Klett-Cotta.

Katan, D. (1999). Translating Cultures. An Introduction for Translators, Interpreters and Mediators. W: J. Munday (red.), The Routledge Companion to Translation Studies (s. 74-92). LondonNew York: Routledge, Taylor \& Francis Group.

Kautz, U. (2000). Handbuch Didaktik des Übersetzens und Dolmetschens. München: Iudicium Verlag. 
Kosyl, C. (1983). Forma i funkcja nazw własnych. Lublin: Uniwersytet Marii Curie-Skłodowskiej.

Kromp, I. (2008). Eigennamen in der deutschen und polnischen Kinderliteratur unter textlinguistischem und translatorischem Aspekt. Frankfurt am Main: Peter Lang.

Labocha, J. (2000). Tekst (Text). W: U. Dąmbska-Prokop (red.), Mała encyklopedia przektadoznawstwa [A small encyclopedia of translation studies] (s. 230-233). Częstochowa: Educator.

Lewicki, R. (2000). Obcość w odbiorze przekładu [Strangeness in the reception of translation]. Lublin: Uniwersytet Marii Curie-Skłodowskiej.

Niebrzegowska-Bartmińska, S. (2017). Jakie dane są relewantne etnolingwistycznie? Etnolingwistyka, 29, 11-28.

Pieciul-Karmińska, E. (2007). Językowy obraz Boga i świata. O przekładzie teologii niemieckiej na język polski [The linguistic image of God and the world: On the translation of German theological writings into Polish]. Poznań: Wydawnictwo Poznańskie.

Sapir, E. (1978). Status lingwistyki jako nauki [The status of linguistics as a science]. W: E. Sapir, Kultura, język, osobowość. Wybrane eseje [Culture, language and personality. Selected essays] (s. 85-95). Warszawa: PIW.

SJP —PWN (b.d.). Stary. W: Stownikjęzyka polskiego PWN.https://sjp.pwn.pl/sjp/stary-I;2523945.html

SJPDor — Doroszewski, W. (red.). (1997). Stownik języka polskiego [cyfrowy reprint wydania książkowego, opublikowanego w Warszawie w 1969 r.]. Warszawa: PWN. https://sjp.pwn.pl/ doroszewski

Thurmair, M. (2002). Eigennamen als kulturspezifische Symbole oder: Was Sie schon immer über Eigennamen wissen wollten. Anglogermanica Online, 2002-1, 84-102. http://epub.uni-regensburg.de/25138/

Tokarski, R. (1980). Brat, brach, braciszek, braciec. W: J. Bartmiński (red.), Stownik ludowych stereotypów językowych. Zeszyt próbny [A dictionary of folk linguistic stereotypes. A trial issue] (s. 69-73).Wrocław: Wydawnictwo Uniwersytetu Wrocławskiego.

Wahrig, G. (1986/1991). Deutsches Wörterbuch mit einem „Lexikon der deutschen Sprachlehre”. Gütersloh-München: Bertelsmann Lexikon Verlag.

Wilkoń, A. (1970). Nazewnictwo w utworach Stefana Żeromskiego [Names in the works of Stefan Żeromski]. Wrocław: Zakład Narodowy im. Ossolińskich.

Yin-Poole, W. (2011, 23 lutego). The brains behind Pokemon Black and White. GameFreak reveals all in a rare interview. Eurogamer. https://www.eurogamer.net/articles/2011-02-22-the-brains-behind-pokemon-black-and-white-interview

Zaw adzki, J. (2015). Dawna literatura chińska. Antologia i omówienie. Tom I (od poczatków do $X$ w. n.e.) [Ancient Chinese literature. An anthology and discussion. Volume I (from its origins to the 10th century AD).]. CreateSpace Independent Publishing Platform.

Zhongguo (2014, 21 maja). Nazwiska i imiona w Chinach [Surnames and given names in China]. Centrum Studiów Polska-Azja (CSPA). http://www.polska-azja.pl/nazwiska-i-imiona-w-chinach/.

Zinken, J. (2016). Jakich danych potrzebuje etnolingwistyka porównawcza? Etnolingwistyka, 28, 334-336.

Źródła internetowe:

http://www.homabooks.com/general/books/east_asia/china/1050.php (dostęp:19.02.2020). 


\section{SUMMARY}

AN ONYMIC IMAGE OF THE WORLD IN TRANSLATION VIA A THIRD LANGUAGE ON THE EXAMPLE OF ANTHROPONYMS IN THE COLLECTION OF STORIES "BAUMMOOS PFLÜCKEN" (LIT. “THE LICHEN COLLECTOR”) BY ZHANG WEI

The onymic image of the world in a translation through an intermediary language as exemplified by the anthroponyms in a collection of short stories "Baummoos pflücken" (lit. "The Lichen Collector") by Zhang Wei.

The article addresses the issue of the linguistic image of the world - reflected in proper names and of its translation. Chinese onyms and their related forms of address contain information about mutual relations between the speaker and the named object, thus offering a better insight into social relations in small language and cultural communities. The challenge for the translator is not only to translate these onyms, but also to preserve their social function in the text. This has been exemplified in the article by a translation of a collection of short stories from Chinese to Polish through German, where the intermediary language adds another coherence layer. The theory of the linguistic image of the world and proper names per se are a starting point for a critical analysis of this specific translation in view of the translation of onyms and of their potential for conveying the image of the world. Emphasis is placed on the transfer of the social functions of onyms into the target language. The influence of onyms and of their consistent treatment in the translation on the coherence of the studied text has also been taken into account.

Keywords: anthroponomastics, cultural linguistics, Chinese anthroponyms, linguistic image of the world, onymic image of the world 